\title{
Analysis of the logistical, economic and minimally invasive cardiac surgical training difficulties in India
}

Ganesh Kumar K. Ammannaya ${ }^{1}$, Marco Solinas², Claudio Passino³

${ }^{1}$ Department of Minimally Invasive Cardiac Surgery, Scuola Superiore Sant'Anna, Pisa, Italy

${ }^{2}$ Department of Adult Cardiac Surgery, G. Pasquinucci Heart Hospital, Fondazione CNR-G. Monasterio, Massa, Italy

${ }^{3}$ Department of Cardiology, Scuola Superiore Sant'Anna, Pisa, Italy

Submitted: 16 April 2020

Accepted: 16 June 2020

Arch Med Sci Atheroscler Dis 2020; 5: e178-e185

DOI: https://doi.org/10.5114/amsad.2020.97380

Copyright $\odot 2020$ Termedia \& Banach

\begin{abstract}
Significant advances have been made in minimally invasive cardiac surgery (MICS) over the past 3 decades. However, the acceptance and practice of MICS continue to remain low in the developing world owing to several challenges. This study aimed to analyse the logistical, economic and training difficulties in MICS with a special focus on the Indian scenario. A systematic review of the current literature on MICS with an emphasis on these challenges was performed. MICS has been shown to have clear cost-benefit advantage that stems from shorter ICU and hospital stay, lesser transfusion requirements and avoidance of sternal wound complications. However, only limited reports are currently available detailing the economic and training challenges for the application of MICS in the developing world, particularly India. Though several challenges exist in widening MICS practice in India, these can be overcome through a target-oriented approach.
\end{abstract}

Key words: minimally invasive cardiac surgery, minimally invasive mitral valve surgery, coronary artery bypass grafting, minimally invasive aortic valve replacement.

\section{Introduction}

The first forays into minimally invasive cardiac surgery (MICS) mitral valve surgery were simultaneously reported by Cosgrove [1] and Cohn et al. [2] and into aortic valve surgery by Cosgrove and Sabik [3] in 1996. Subsequently, video assistance was introduced by Carpentier et al. [4], transthoracic aortic clamping by Chitwood et al. [5], port access by the Leipzig group headed by Mohr et al. [6] and robotic computer assisted surgery by Carpentier et al. [7].

As we stand today, most intracardiac pathologies have a parallel minimally invasive or transcatheter solution to the standard sternotomy route. MICS has been continuously gaining traction, so much so that, in some centres across the world, MICS is a default strategy for most cardiac procedures. MICS thus seems to be finding favour with the patients who are demanding these less invasive procedures and also the industry seems to be willing to sponsor it.

Clearly MICS has several advantages - a certain cosmetic advantage, reduces blood loss and transfusion requirements, shortens the length

\author{
Corresponding author: \\ Dr. Ganesh Kumar K. \\ Ammannaya MS, MCH, \\ FEBCTS, FACS, FICS, FACC \\ Department of Minimally \\ Invasive Cardiac Surgery \\ Scuola Superiore \\ Sant'Anna \\ Pisa, Italy \\ E-mail: doc.ammannaya@ \\ gmail.com
}


of hospital stay and avoids the potentially devastating infective problems of mediastinitis/sternal dehiscence besides reducing the post-operative recovery time and early return to work [8].

The level of acceptance of MICS in some of the major emerging economies such as India compares rather dismally with the European countries. This is summarized from pooled data as shown in Table I [9].

As evident from the table above, the level of acceptance and application of MICS seems to be the highest in Germany, where $50 \%$ of isolated valvular heart procedures were performed through MICS in the year 2016 (about 8500 from a little over 17,000 cases). These rates have increased in particular over the past 10 years. In comparison to the European nations, the practice of MICS in India is still in its infancy.

From the various pooled data, a rough estimate of the percentage of MICS being performed in India for the various cardiac procedures in India is presented in Table II [9].

From the above table, it is clear that the scope for scale up of MICS in India is tremendous. About 58,000 valvular heart procedures are performed in India as against about 17,000 in Germany; but the absolute numbers performed through MICS compare as follows: 2300 (India) vs. 8500 (Germany). In other words, with over three times the patient volume, MICS valvular procedures in India are performed three times less frequently. Hence, we can safely conclude that the scenario in India is ripe for the introduction of MICS and a huge scale up subsequently.

However, the challenges are huge. With the rapid strides made by MICS, a few pertinent questions that need to be asked are: Do the extensive economic and logistical resources required for these procedures justify their propagation in developing countries? How do these less invasive procedures compare with the conventional sternotomy approach with respect to economic viability? Being technically demanding, can MICS be taught with a reasonable learning curve without compromising the patient's interests? Therefore, this study was performed with the objective of exploring the various difficulties, challenges and feasibility of the application of MICS with respect to its economics, logistics and training in India.

\section{Material and methods}

A systematic and structured review of the current literature on MICS with an emphasis on the economic, logistical and training challenges was performed on the basis of pertinent studies and database studies retrieved by a selective search in the Medline/PubMed Central and EMBASE/ SCOPUS databases as well as by the Google Scholar search engine.
Separate keywords were entered each time to obtain specific information such as - "economics of minimally invasive mitral valve surgery"/“cost benefit analysis of minimally invasive mitral valve surgery", "economics of minimally invasive aortic valve surgery"/"cost benefit analysis of minimally invasive aortic valve surgery", "economics of minimally invasive CABG"/“cost benefit analysis of minimally invasive CABG"/"economics of MICS CABG"/ "cost benefit analysis of MICS CABG". Furthermore, the Boolean operator "AND" was used to extract information and data pertaining to India as follows - "economics of minimally invasive cardiac surgery AND India"/ cost benefit analysis of minimally invasive cardiac surgery AND India" and "training of minimally invasive cardiac surgery AND India".

The references of identified articles were reviewed to detect relevant information and to identify any additional related articles. Studies not published as full-text articles, single case reports and articles not written in English were excluded. No article was excluded based on publication date.

\section{Results}

As of 31 August 2019, searches of the databases yielded nearly 11,694 hits. However, only limited reports were available detailing the economic and training challenges for the application of MICS in the developing world, particularly India. All studies carrying relevant data from these databases were pooled for this study.

Table I. Percentage of valvular heart procedures performed through MICS - Europe vs. India [9]

\begin{tabular}{|lc|}
\hline Country & $\begin{array}{c}\text { \% of isolated valvular heart procedures } \\
\text { done through MICS }\end{array}$ \\
\hline Germany & 50 \\
\hline Italy & 25 \\
\hline France & 25 \\
\hline Spain & $20 \%$ \\
\hline Denmark & $20 \%$ \\
\hline Poland & 11 \\
\hline UK & 10 \\
\hline India & 4 \\
\hline
\end{tabular}

Table II. Percentage of heart procedures performed through MICS - Indian scenario [9]

\begin{tabular}{|lcc|}
\hline Type of cardiac surgery & $\begin{array}{c}\text { Total vol- } \\
\text { ume }\end{array}$ & $\begin{array}{c}\% \text { of proce- } \\
\text { dures done } \\
\text { through } \\
\text { MICS }\end{array}$ \\
\hline Valvular heart surgery & $\sim 58,000$ & 4 \\
\hline Coronary surgery (CABGs) & $\sim 95,000$ & $5-6$ \\
\hline Congenital surgery & $\sim 40,000$ & 3 \\
\hline
\end{tabular}




\section{Minimally invasive mitral valve surgery (MIMVS) vs. conventional mitral valve surgery}

The results of the review of the economic analysis of minimally invasive mitral valve surgery (MIMVS) vs conventional mitral valve surgery is summarized in Table III [10-13]. Since 1998, at least four studies have shown a clear cost benefit of MIMVS. The lower cost entailed in MIMVS stems from the fact that these patients require a shorter hospital stay, fewer blood transfusions, improved resource utilization and lower sepsis/ avoidance of sternal wound complications.

\section{Minimally invasive aortic valve surgery vs. conventional aortic valve surgery}

The results of the review of the economic analysis of minimally invasive aortic valve surgery vs. conventional aortic valve surgery are summarized in Table IV [14-16]. Studies performed by Ghanta et al. and Rodriguez et al. have shown a clear cost benefit of minimally invasive aortic valve replace-

Table III. Economic analysis of minimally invasive mitral valve surgery (MIMVS) vs. conventional mitral valve surgery

\begin{tabular}{|c|c|c|c|c|}
\hline $\begin{array}{l}\text { Author (year), journal } \\
\text { and country [ref.] } \\
\text { Study type } \\
\text { (level of evidence) }\end{array}$ & $\begin{array}{c}\text { Number } \\
\text { of patients }\end{array}$ & Outcomes & Key results & Comments \\
\hline $\begin{array}{l}\text { Grossi et al. (2014), } \\
\text { J Thorac Cardiovasc } \\
\text { Surg, USA [10] } \\
\text { Propensity-matched, } \\
\text { (level } 3 \text { evidence) }\end{array}$ & $\begin{array}{l}M T=367 \\
S T=367\end{array}$ & $\begin{array}{l}\text { Operative, ICU, } \\
\text { and total hospital } \\
\text { costs }\end{array}$ & $\begin{array}{c}\text { Mean operating } \\
\text { costs of MT }(\$ 9602) \\
>\text { ST }(\$ 8929) \text {. } \\
\text { MT was associated } \\
\text { with reduced } \\
\text { median ICU cost } \\
\text { (\$2622 vs. } \$ 4177) \\
\text { and total hospital } \\
\text { cost }(\$ 31,515 \text { vs. } \\
\$ 37,495), \text { when } \\
\text { compared with ST }\end{array}$ & $\begin{array}{l}\text { MT provided significant cost } \\
\text { savings, driven by a lower } \\
\text { sepsis and infection rate } \\
\text { (1.1 vs. } 4.4 \%, p=0.0065) \\
\text { and shorter hospital stay } \\
\text { (7.9 vs. } 10.2 \text { days), when } \\
\text { compared with ST. } \\
\text { Furthermore, lower } \\
\text { readmission rates observed } \\
\text { in MT at } 30 \text { days ( } 26.2 \text { vs. } \\
\text { ST } 35.7 \%, p<0.0052) \text { and } \\
90 \text { days ( } 31.6 \text { vs. } 44.1 \%, p< \\
\text { 0.0005) may translate into } \\
\text { additional cost savings }\end{array}$ \\
\hline $\begin{array}{l}\text { Iribarne et al. (2012), } \\
\text { J Thorac Cardiovasc } \\
\text { Surg, USA [11] } \\
\text { Retrospective study } \\
\text { (level } 3 \text { evidence) }\end{array}$ & $\begin{array}{l}M T=70 \\
S T=105\end{array}$ & $\begin{array}{c}\text { Total hospital } \\
\text { cost }\end{array}$ & $\begin{array}{c}\text { MT } \$ 37,069 \text { vs. } \\
\text { ST } \$ 43,790 \\
p=0.007\end{array}$ & $\begin{array}{l}\text { MT was associated with } \\
\text { reduced hospital costs, } \\
\text { driven by decreased } \\
\text { length of hospital stay and } \\
\text { improved resource utilization } \\
\text { and postoperative functional } \\
\text { status when compared } \\
\text { with ST. Length of hospital } \\
\text { Stay MT } 5.1 \pm 0.9 \text { vs. } \\
\text { ST } 8.6 \pm 0.6 \text { days, } \\
p=0.033\end{array}$ \\
\hline $\begin{array}{l}\text { Gersak et al. (2005), } \\
\text { Heart Surg Forum, } \\
\text { Slovenia [12] } \\
\text { Retrospective study } \\
\text { (level } 3 \text { evidence) }\end{array}$ & $\begin{array}{l}\text { Minimally } \\
\text { invasive } \\
\text { port-access MV } \\
\text { surgery }=105 ; \\
\text { ST }=110\end{array}$ & $\begin{array}{l}\text { Mean costs of } \\
\text { hospitalization, } \\
\text { Units of blood } \\
\text { transfused } \\
\text { and hospital } \\
\text { length of stay }\end{array}$ & $\begin{array}{l}\text { The average total } \\
\text { patient cost was } \\
20 \% \text { less for } \\
\text { the port-access } \\
\text { group, } p<0.0005 \text {. } \\
\text { Port-access } 2.1 \text { vs. } \\
\text { ST } 3.6 \text { units, } \\
p<0.0001 \text {. Port- } \\
\text { access } 5.1 \text { vs. } \\
\text { ST } 8.6 \text { days, } \\
p<0.0001\end{array}$ & $\begin{array}{l}\text { Port-access surgery was } \\
\text { associated with significant } \\
\text { reductions in resource } \\
\text { utilization and costs }\end{array}$ \\
\hline $\begin{array}{l}\text { Cosgrove et al. (1998), } \\
\text { Ann Thorac Surg, USA } \\
\text { [13] } \\
\text { Retrospective study } \\
\text { (level } 3 \text { evidence) }\end{array}$ & $\begin{array}{l}M T=49 \\
S T=40\end{array}$ & $\begin{array}{l}\text { Total hospital } \\
\text { cost, hospital } \\
\text { length of stay }\end{array}$ & $\begin{array}{c}7 \% \text { less in } \\
\text { MT }(\$ 5800) \text { vs. } \\
\text { ST }(\$ 6250) \text {, after } \\
\text { removing the costs } \\
\text { of prosthetic valves; } \\
\text { MT } 5.7 \text { vs. } \\
\text { ST } 6.2 \text { days } \\
\text { ( } p=\text { not significant })\end{array}$ & $\begin{array}{l}\text { Low rates of complications in } \\
\text { MT, including } 0 \% \text { mortality, } \\
14 \% \text { incidence of required } \\
\text { blood transfusions and } \\
\text { relatively shorter length of } \\
\text { hospital stay }\end{array}$ \\
\hline
\end{tabular}

MT - mini thoracotomy, ST - sternotomy. 
ment (mini-AVR) vs. full sternotomy AVR in terms of reduced ICU and hospital stay and decreased transfusion requirements. Hassan et al. further showed that the cost saving is further much greater in mini sternotomy AVR as compared to right anterior thoracotomy (RAT) AVR.

\section{Minimally invasive coronary artery bypass grafting (CABG) vs. conventional CABG}

The results of the review of the economic analysis of minimally invasive coronary artery bypass grafting $(\mathrm{CABG})$ vs. conventional CABG are summarized in Table $V[17,18]$. Poston et al. showed that MICS CABG was associated with earlier return to work along with significant hospital savings arising out of shorter intubation time, shorter hospital stay and lower transfusion requirements. In an earlier study by King et al., authors showed a cost-benefit advantage of MICS CABG vs. both percutaneous transluminal coronary angioplasty (PTCA) and conventional CABG.

\section{MICS in India - the current state of affairs from the economic, logistical and training perspectives}

The low level of MICS embracement in India is due to the high initial capital intensive investment

Table IV. Economic analysis of minimally invasive aortic valve surgery vs. conventional aortic valve surgery

\begin{tabular}{|c|c|c|c|c|}
\hline $\begin{array}{l}\text { Author (year), } \\
\text { journal and country } \\
\text { Study type } \\
\text { (level of evidence) }\end{array}$ & $\begin{array}{l}\text { Number } \\
\text { of patients }\end{array}$ & Outcomes & Key results & Comments \\
\hline $\begin{array}{l}\text { Ghanta et al. (2015). } \\
\text { J Thorac Cardiovasc } \\
\text { Surg, USA [14] } \\
\text { Retrospective study } \\
\text { (level } 3 \text { evidence) }\end{array}$ & $\begin{array}{l}\text { Mini AVR }=442 \\
\text { ST AVR }=899\end{array}$ & $\begin{array}{l}\text { Ventilator time; blood } \\
\text { product transfusion; } \\
\text { total hospital costs }\end{array}$ & $\begin{array}{c}\text { Mini-AVR was } \\
\text { associated with } \\
\text { decreased ventilator } \\
\text { time ( } 5 \text { vs. } 6 \mathrm{~h} ; \\
p=0.04) \text { and } \\
\text { decreased blood } \\
\text { product transfusion } \\
(25 \% \text { vs. } 32 \% \text {; } \\
p=0.04) \text {. } \\
\text { Total hospital costs } \\
\text { were lower in the } \\
\text { mini-AVR group } \\
(\$ 36,348 \text { vs. } \$ 38,239 ; \\
p=0.02)\end{array}$ & $\begin{array}{c}\text { Mini-AVR is } \\
\text { associated } \\
\text { with decreased } \\
\text { ventilator time, } \\
\text { blood product use, } \\
\text { early discharge, } \\
\text { and reduced total } \\
\text { hospital cost }\end{array}$ \\
\hline $\begin{array}{l}\text { Hassan et al. (2015). } \\
\text { Journal of Heart Valve } \\
\text { Disease, USA [15] } \\
\text { Retrospective } \\
\text { database-based study } \\
\text { (level } 3 \text { evidence) }\end{array}$ & $\begin{array}{l}\text { RAT AVR was } \\
\text { compared with } \\
\text { MST AVR through } \\
8 \text { reports from } \\
\text { the United States } \\
\text { were selected } \\
\text { from amongst } \\
\text { 33,494 literature } \\
\text { citations based on } \\
\text { sample size }\end{array}$ & $\begin{array}{c}\text { Rate of blood } \\
\text { transfusion; length of } \\
\text { hospital stay }\end{array}$ & $\begin{array}{c}\text { MST AVR was } \\
\text { associated with } \\
\text { lower rate of blood } \\
\text { transfusion } \\
\text { (25.9\% vs. } 64.4 \%), \\
\text { and a shorter length } \\
\text { of hospital stay } \\
\text { (5.7 vs. } 6.2 \text { days) }\end{array}$ & $\begin{array}{l}\text { Clinical benefits } \\
\text { of MST AVR } \\
\text { are comparable } \\
\text { or better than } \\
\text { those of RAT AVR } \\
\text { at lower costs. } \\
\text { Assuming a volume } \\
\text { of } 50 \text { cases per } \\
\text { year, the added } \\
\text { operative cost per } \\
\text { case for a RAT AVR } \\
\text { was US\$ } 4,254 \\
\text { compared to US\$ } \\
290 \text { for a MST AVR. } \\
\text { The added costs } \\
\text { per case, assuming } \\
200 \text { cases per year, } \\
\text { were US\$ } 4,209 \\
\text { and US\$ } 290, \\
\text { respectively }\end{array}$ \\
\hline $\begin{array}{l}\text { Rodriguez et al. } \\
\text { (2014) } \\
\text { J Med Econ USA [16] } \\
\text { Propensity-matched, } \\
\text { (level } 3 \text { evidence) }\end{array}$ & $\begin{array}{c}\text { RAT }=1572 \\
\text { ST }=3962 \\
\text { (Propensity } \\
\text { matched }-921 \\
\text { patients each) }\end{array}$ & $\begin{array}{l}\text { Blood product cost; } \\
\text { Overall hospital cost }\end{array}$ & $\begin{array}{c}\text { Less blood product } \\
\text { cost associated with } \\
\text { RAT }(\$ 1381 \text { vs. } \$ 1912 ; \\
p<0.001) \\
\text { RAT-AVR associated } \\
\text { with lower cost than } \\
\text { ST-AVR }(\$ 38,769 \text { vs. } \\
\$ 42,656 ; p<0.01)\end{array}$ & $\begin{array}{c}\text { Less cost and ICU } \\
\text { time with RAT-AVR } \\
\text { Vs ST-AVR }\end{array}$ \\
\hline
\end{tabular}


Table V. Economic analysis of minimally invasive coronary artery bypass grafting (CABG) vs. conventional CABG

\begin{tabular}{|c|c|c|c|c|}
\hline $\begin{array}{l}\text { Author (year), } \\
\text { journal and country } \\
\text { Study type } \\
\text { (level of evidence) }\end{array}$ & $\begin{array}{l}\text { Number } \\
\text { of patients }\end{array}$ & Outcomes & Key results & Comments \\
\hline $\begin{array}{l}\text { Poston et al. (2008), } \\
\text { Ann Surg USA [17] } \\
\text { Propensity-matched, } \\
\text { (level } 3 \text { evidence) }\end{array}$ & $\begin{array}{c}\text { MICS } \\
C A B G=100 \\
C A B G=100\end{array}$ & $\begin{array}{l}\text { Intubation time, } \\
\text { hospital stay, } \\
\text { transfusion }\end{array}$ & $\begin{array}{l}\text { Postoperative costs } \\
\text { were decreased from } \\
\text { significantly less } \\
\text { intubation time } \\
(4.80 \pm 6.35 \text { vs. } 12.24 \\
\pm 6.24 \text { h), shorter } \\
\text { hospital stay } \\
(3.77 \pm 1.51 \text { vs. } 6.38 \\
\pm 2.23 \text { days), and } \\
\text { lower transfusion } \\
\text { requirements } \\
(0.16 \pm 0.37 \text { vs. } \\
1.37 \pm 1.35 \cup) \text {. } \\
\text { Analysis with the } \\
\text { groups stratified } \\
\text { according to risk } \\
\text { revealed that } \\
\text { MICS CABG had } \\
\text { a significantly more } \\
\text { favourable cost } \\
\text { efficiency ( } 0.62 \pm 0.16 \\
\text { vs. } 0.81 \pm 0.17 ; \\
p<0.05) \text { and profit } \\
\text { margin ( } 25,132 \pm 6086 \\
\text { vs. } 15,653 \pm 8141 ; \\
p=0.01)\end{array}$ & $\begin{array}{l}\text { Undergoing MICS } \\
\text { CABG independently } \\
\text { predicted earlier } \\
\text { return to work } \\
\text { after adjusting for } \\
\text { confounders } \\
(t=-2.15 ; p=0.04) \\
\text { along with a superior } \\
\text { cost efficiency }\end{array}$ \\
\hline $\begin{array}{l}\text { King et al. (1997), Heart } \\
\text { Surg Forum, USA [18] } \\
\text { Retrospective study. } \\
\text { (level } 3 \text { evidence) }\end{array}$ & $\begin{array}{c}\text { MICS CABG }=9 \\
\text { CABG }=9 \\
\text { PTCA }=10\end{array}$ & Total hospital costs & $\begin{array}{l}\text { Total hospital costs } \\
\text { for the MICS CABG } \\
\text { and PTCA groups } \\
\text { were significantly less } \\
\text { than those of stan- } \\
\text { dard CABG }(\$ 11,233 \text {, } \\
\$ 12,152, \text { vs. } \$ 18,859 \\
\text { respectively, } \\
\quad p=0.0028)\end{array}$ & $\begin{array}{l}\text { MICS CABG is } \\
\text { clearly cost effective } \\
\text { when compared } \\
\text { with PTCA and } \\
\text { conventional CABG }\end{array}$ \\
\hline
\end{tabular}

during the setting up of a new MICS centre [19]. There have been a few bright spots of how MICS was successfully introduced. Reddy et al. [20] report in their article dated 2013 of how MICS was introduced on a small scale with about 70 procedures being performed in the period 2012-2013. These included 25 MIMVR, 10 mini-AVRs, 30 ASD closures and 5 MICS CABG. The team faced significant challenges with 2 cases requiring conversion to sternotomy, about 10 patients developed minor air leak which subsided spontaneously, a case of right lower limb oedema related to femoral vein cannulation and another case of surgical site infection. However, the overall results were encouraging and the team carried on and has been performing about 80-100 cases of MICS annually.

Today, of the nearly $2,00,000$ cardiac procedures that are performed in India, only about 11000-12000 cases are done through the MICS route. Of nearly 700 cardiac centres in India, only about 90 have attempted or have performed cases of MICS either regularly or irregularly, which accounts for only about a $12-13 \%$ attempt rate for MICS. Mishra [21] has given a pragmatic and a highly feasible solution to increase this number through his concept of "Public-Private Partnership (PPP)". The PPP model is a clever policy to utilize the excellence of booming private tertiary care centres in India for the poor people. The government, thus, could have a win-win deal for every one because it can avoid the investment and maintenance cost of infrastructure and protecting precious tax payers' money, while private tertiary care hospitals get increased demand for advanced facilities by the addition of government sponsored patients, though at a skewed profit margin. It also keeps the beds and staff engaged. On the flip side, there are issues of heavy paper work, delayed passages of bills and payments. If these are looked into and rectified, a flourishing PPP model can be 
created in India and the practice of MICS in India can approach the European standards over the coming $3-5$ years.

Certain other indigenous methods have also been put to practice in the Indian scenario to circumvent the higher cost of peripheral cannulation. Kandakure et al. [22] report the routine use of direct cannulation in MICS in centres with limited resources to mitigate the cost as regular instruments and cannulae are used. Over a 2-year period (January 2017 - December 2018), the authors report a total of 140 cases of MICS (ASD closure (53\%), mitral valve repair (14\%), VSD closure $(9 \%)$, aortic valve replacement (10\%), mitral valve replacement (6\%), repair of PAPVC (9\%), myxoma excision (1\%), VSD closure with pulmonary valvotomy $(1 \%))$, being performed with central cannulation. Similarly, Kale and Ramalingam [23] reported 145 cases of MICS performed through October 2015 to March 2017, without peripheral cannulation. The cases operated on included those performed through right anterior thoracotomy - MIMVR, ASD closures, VSD closures and correction of TOF. Right anterior thoracotomy without peripheral cannulation was found to be safe and effective for the correction of a wide range of congenital heart defects including right ventricular outlet obstructions.

Endoscopic cardiac procedures are nearly non-prevalent in the country owing to the extremely high costs of the initial set up that ranges from $€ 75,000$ to $1,00,000$ and a high number of cases required to break even. These can be aimed as a gradual progression from thoracotomy, once an existing MICS centre gains experience and begins delivering results that are at par with the standards of today.

Another major detriment to the successful application of MICS on a large scale is the lack of training facilities [21]. Training infrastructure in India is limited and there are no skills laboratories with advanced simulation-based teaching facilities including premier institutes and some of the best heart centres. Moreover, there is not a single fellowship programme dedicated to MICS in the country. Therefore, there are neither formal nor informal training opportunities for MICS in India at the present moment and all interested surgeons have no choice but to embark on foreign fellowships either in the US or Europe to learn these advanced techniques. Therefore, it is of utmost importance to introduce training curriculums for MICS in India so as to avoid the over-dependence on foreign fellowships which not many can afford. The governing medical bodies of the country must take note of the changing needs in the practice of cardiac surgery and address the issue by offering training facilities through establishing new fellowship programmes and also setting up skills laboratories and simulator centres to help further shorten the learning curve [21].

\section{Discussion}

From the several aforementioned studies it can be safely concluded that MICS has a distinct economic advantage with respect to overall lower hospital costs. This has been shown in MIMVR, mini-AVR and MICS CABG and also MICS in general. However, most of these studies are performed in the USA. More such studies are needed particularly in the developing countries such as India, which would help confirm these facts and help the faster spread of MICS in India.

Education regarding the cost benefit of MICS especially in the post-operative course and early return to work resulting in higher efficiency needs to be spread in the Indian scenario to draw more surgeons into the MICS mainstream. Further, a conducive atmosphere of an amicable public private partnership can help greatly strengthen the logistics of MICS practice in India. The state of cardiac surgery in the developing countries is ripe for the era of MICS. Careful patient selection aiming to "tailor the operation to the patient and not the patient to the operation" is the crux of a successful MICS programme.

India has been an ideal place for excellent cost-effective medical treatments, particularly for patients from SAARC countries, Africa, the Middle East, and Central Asia. India is a leading developing nation which has participated in achieving the goals laid down under the Millennium Development Goals - 2015, Vision - 2020 and subsequently under the Sustainable Development Goals - 2030. Recently, the Indian government has been appreciated for its effort in bringing down the cost of devices. India has also launched the "Ayushman Bharat" or "Modi Care" which is being hailed as the largest public sector health cover in the world by the prestigious Lancet journal. Therefore, the future holds great promise and this opportunity needs to be seized by the present generation of cardiac surgeons. We are thus at a critical and strategic inflection point in the evolution of cardiac surgery. It has been challenged both by our cardiology counterparts and as a self-challenge within the cardiac surgical community, more as a survival response than anything else. We thus need to evolve continuously and keep reinventing ourselves rather than repeat the mistake of the 1970 s and 1980s of developing the 'inertia of success'.

A target oriented approach has to be formulated by the major governing medical bodies of the country to improve teaching and training facilities. These should include facilitating research and development, performing multicentric studies 
to better understand the Indian scenario, more workshops and simulation-based hands-on experience or skills laboratories designed to hone the skills required for MICS and also on hybrid technologies such as wires and catheters. Introduction of indigenous fellowship programmes under the mentorship of existing MICS surgeons is the need of the hour. Also, trainees may be allowed to go and work in another centre in or out of India, for at least 4 weeks, to enhance training experiences, which can be sponsored by the medical college hospitals and industry alike.

New MICS surgeons can continuously monitor their own progress and learning curve or can be looked upon by the heads of the department through CUSUM curve analysis, which is a simple statistical method [24]. It will be successful if surgeons embrace new technologies in imaging, videoscopy, and catheter-based interventions. Technology transfer at regional and global platform and transferring effective technology from developed centres to centres of learning and reducing import duties and levies on implantable coronary and other devices and machines can further go a long way in achieving the goals of a much wider application and practice of MICS in India.

Minimally invasive cardiac surgery has been seen to flourish in heart team environments, as evident in Western Europe. The same has to be inculcated in India. Finally, there is a strong need of a database. There have been successful efforts to create a global database for cardiac procedures such as the STS database; however, the lack of national databases in India is hurting the realistic monitoring of the growth of MICS and the evaluation of its results vis-à-vis conventional cardiac procedures.

In conclusion, there is no denying that several challenges do exist in the successful application and practice of MICS in India on a large scale. These are mainly economic, logistical and the lack of training facilities and programmes. However, these can be overcome through a strong-willed target oriented approach with the aid of the public sector, which can foster a lasting partnership with the private healthcare, and also by the setting up of training curriculums as well as skills laboratories and simulation centres to roll out MICS surgeons to meet the needs of present day cardiac surgery.

\section{Conflict of interest}

The authors declare no conflict of interest.

\section{References}

1. Cosgrove DM. Minimally invasive mitral valve operations. Ann Thorac Surg 1996; 62: 1542-4.
2. Cohn LH, Adams DH, Couper GS, et al. Minimally invasive cardiac valve surgery improves patient satisfaction while reducing costs of cardiac valve replacement and repair. Ann Surg 1997; 226: 421-8.

3. Cosgrove DM $3^{\text {rd }}$, Sabik JF. Minimally invasive approach for aortic valve operations. Ann Thorac Surg 1996; 62: 596-7.

4. Carpentier A, Loulmet D, Carpentier A, et al. Open heart operation under videosurgery and minithoracotomy first case (mitral valvuloplasty) operated with success. CR Acad Sci 1996; 319: 219-23.

5. Chitwood WR Jr, Elbeery JR, Chapman WH, et al. Video-assisted minimally invasive mitral valve surgery: the 'micro-mitral' operation. J Thorac Cardiovasc Surg 1997; 113: 413-4.

6. Mohr FW, Falk V, Diegeler A, Walther T, van Son JA, Autschbach R. Minimally invasive port-access mitral valve surgery. J Thorac Cardiovasc Surg 1998; 115: 567-76.

7. Carpentier $A$, Loulmet $D$, Aupècle et al. Computer assisted open heart surgery - first case operated on with success. CR Acad Sci III 1998; 321: 437-42.

8. Yamada T, Ochiai R, Takeda J, Shin H, Yozu R. Comparison of early postoperative quality of life in minimally invasive versus conventional valve surgery. J Anesth 2003; 17: 171-6.

9. Doshi C. MICS CABG - as a routine approach to Indian paients. Paper presented at Annual Conference of Society of Minimally Invasive Cardiothoracic Surgery of India; Mumbai; 2019 Sep 13-15.

10. Grossi EA, Goldman S, Wolfe JA, et al. Minithoracotomy for mitral valve repair improves inpatient and postdischarge economic savings. J Thorac Cardiovasc Surg 2014; 148: 2818-22.

11. Iribarne A, Easterwood R, Russo MJ, Chan EY, Smith CR, Argenziano M. Comparative effectiveness of minimally invasive versus traditional sternotomy mitral valve surgery in elderly patients. J Thorac Cardiovasc Surg 2012; 143: S86-90.

12. Gersak B, Sostaric M, Kalisnik JM, Blumauer R. The preferable use of port access surgical technique for right and left atrial procedures. Heart Surg Forum 2005; 8: E354-63.

13. Cosgrove DM III, Sabik JF, Navia JL. Minimally invasive valve operations. Ann Thorac Surg 1998; 65: 1535-8.

14. Ghanta RK, Lapar DJ, Kern JA, et al. Minimally invasive aortic valve replacement provides equivalent outcomes at reduced cost compared with conventional aortic valve replacement: a real-world multi-institutional analysis. J Thorac Cardiovasc Surg 2015; 149: 1060-5.

15. Hassan M, Miao Y, Maraey A, et al. Minimally invasive aortic valve replacement: cost-benefit analysis of ministernotomy versus minithoracotomy approach. J Heart Valve Dis 2015; 24: 531-9.

16. Rodriguez E, Malaisrie SC, Mehall JR, et al.; Economic Workgroup on Valvular Surgery. Right anterior thoracotomy aortic valve replacement is associated with less cost than sternotomy-based approaches: a multi-institution analysis of 'real world'data. J Med Econ 2014; 17: 846-52.

17. Poston RS, Tran R, Collins M, et al. Comparison of economic and patient outcomes with minimally invasive versus traditional off-pump coronary artery bypass grafting techniques. Ann Surg 2008; 248: 638-46.

18. King RC, Reece TB, Hurst JL, et al. Minimally invasive coronary artery bypass grafting decreases hospital stay and cost. Ann Surg 1997; 225: 805-9.

19. Yadava OP. Minimally invasive cardiac surgery - a push to kaizen! Indian J Thorac Cardiovasc Surg 2018; 34 (Suppl 2): S81-3. 
20. Reddy SC, Parimi SS, Tella R, Chunduru K, Syed NA. Initiating a minimally invasive cardiac surgery program - challenges and solutions. Indian J Thorac Cardiovasc Surg 2013; 29: 98.

21. Mishra YK. Quest of affordable cardiac care with public-private partnership: a way forward to the future! Indian J Thorac Cardiovasc Surg 2019; 35: 139-45.

22. Kandakure PR, Batra M, Garre S, et al. Direct cannulation in minimally invasive cardiac surgery with limited resources. Ann Thorac Surg 2020; 109: 512-6.

23. Kale SB, Ramalingam S. Minimally invasive cardiac surgery without peripheral cannulation: a single centre experience. Heart Lung Circ 2019; 28: 1728-34.

24. Wu X, Wei W, He Y, et al. Analysis of the learning curve in mitral valve replacement through the right anterolateral minithoracotomy approach: a surgeon's experience with the first 100 patients. Heart Lung Circ 2019; 28 471-6. 